\section{Note on preserving a standard suspension of live vibrios}

H. K. GHOSH, W. H. R. LUMSDEN, AND GILLIAN J. C. HARDY From the Department of Bacteriology, University of Edinburgh Medical School, and the Trypanosomiasis Research Unit, Royal (Dick) School of Veterinary Studies, University of Edinburgh

It is difficult to prevent changes in biological characters of vibrio strains during storage (Martin, 1964). Even freeze-drying may be unsatisfactory for two reasons. First, only about $5 \%$ of viable cells survive the process (Fry and Greaves, 1951) allowing chance for selection of variants. Secondly, the viable cell count of each suspension made from regenerated cultures has to be ascertained. This may lead to large deviations from the intended dose because the number of vibrios in suspensions of equal optical density varies unusually widely (Maaløe,

Received for publication 10 November 1965

\section{Simultaneous demonstration of mast cells} and plasma cells - concluded

The $p \mathrm{H}$ of the Alcian blue solution in this method is low, approximately 0.5 , and it is important that the section is allowed the full time in the acid alcohol solution (stage 2), otherwise other tissue elements will take up the Alcian blue stain; this cuts down the contrast in the final picture. As the staining of the methyl greenpyronin solution is impaired in very acid conditions, it is essential that the sections are well washed after treatment with Alcian blue.

Solutions B and C can be used separately. For the demonstration of mast cells, steps 1-5 are carried out, followed by a nuclear counterstain, e.g., $1 \%$ neutral red. For plasma cells, the section is brought to distilled water, and steps 6-10 are carried out.

Generally the mast cells stain a deep turquoise-blue, but it has been observed that some cells, cytologically resembling mast cells, stain purple.

We wish to thank Dr. N. F. C. Gowing, Director of the Department, for permision to publish this technique, and Dr. I. M. E. Hamlin for her encouragement and advice.

\section{REFERENCES}

Dacie, J. V. (1950). Practical Haematology, 1st ed., p. 69. Churchill London.

Johnson, W. C., and Helwig, E. B. (1963). Ann, N.Y. Acad. Sci. 106, p. 794

McManus, J. F. A., and Mowry, R. W. (1960). Staining Methods, Histologic and Histochemical, p. 136. Hoeber, New York.
1955), and the viable count is not available till the next day. Thus McIntyre and Feeley (1964) noted fifteenfold variations in their challenge doses during a passive protection test. We have, therefore, investigated the possibility of storing a vibrio suspension of known viable count at a very low temperature, i.e., of preparing a vibrio stabilate. (A stabilate has been defined by Lumsden and Hardy (1965) as 'a population of an organism preserved in viable condition on a unique occasion'.)

Martin (1964) has reviewed the principles of storing microbes at temperatures below $-55^{\circ} \mathrm{C}$. The problem is to prevent cell death during freezing and thawing. Addition of glycerol or dimethylsulphoxide reduces cell death with some organisms. Once successfully frozen, microbes seem to keep indefinitely without noticeable change.

\section{MATERIALS AND METHODS}

Vibrio cholerae 12R (Ogawa) was received from the National Institutes of Health, U.S.A. (McIntyre and Feeley, 1964). V. eltor H2 (Ogawa) was sent by Dr. M. Robertson, Queen Elizabeth Hospital, Hong Kong; it had been isolated from a cholera patient in 1963. Both strains were received freeze-dried. The contents of each ampoule were suspended in $0.2 \mathrm{ml}$. of nutrient broth (Oxoid no. 2) and streaked on a nutrient agar plate ( $p \mathrm{H} 8.0$ to 8.4). After incubating for 18 to 20 hours at $37^{\circ} \mathrm{C}$. the growth was freeze-dried in a large number of ampoules.

PREPARATION OF A STABILATE The contents of an ampoule were cultured as above. Portions of five to six colonies were streaked on a nutrient agar slope and incubated overnight. The growth was suspended in $2 \mathrm{ml}$. of broth, and divided in two portions. To one part was added sterile glycerol $(7 \cdot 5 \% \mathrm{v} / \mathrm{v})$, the second portion received no preservative. In early experiments sterile Analar grade dimethylsulphoxide was added to a third portion to a final concentration of $10 \%(\mathrm{v} / \mathrm{v})$. The suspensions were filled into capillary lymph tubes and then frozen and stored in solid carbon dioxide $\left(-79^{\circ} \mathrm{C}\right.$.) as described by Cunningham, Lumsden, and Webber (1963).

DETERMINATION OF VIABLE COUNT A tube was opened at both ends and weighed. The contents were expelled in $1 \mathrm{ml}$. of diluent $(0.1 \%$ peptone in $0 \cdot 15 \mathrm{M}$ saline, $p \mathrm{H}$ $7 \cdot 0$ to $7 \cdot 2$ ), and the tube was weighed again. The volume of diluent was adjusted to contain $10 \mathrm{mg}$. of stabilate in each millilitre. A series of tenfold dilutions was made. With a $0.1 \mathrm{ml}$. pipette, $0.1 \mathrm{ml}$. of each dilution was delivered on each of two agar plates and spread with the bent tip of Pasteur pipettes. After overnight incubation the colonies on both plates from an appropriate dilution (giving 100 to 300 colonies per plate) were counted. The number of colony-forming units in each milligram of undiluted stabilate was computed from the average.

At least two tubes at a time were examined immediately before freezing and after storage for 48 hours.

INFECTING SUCKLING RABBITS A litter of 11-day-old rabbits was infected as described by McIntyre and 
Feeley (1964) except that the inoculum (500 colonyforming units of $V$. cholerae 12R) was injected into the duodenum exposed through a right subcostal incision. One animal was killed with ether when it developed diarrhoea 20 hours later. The watery fluid in its caecum was mixed with an equal volume of normal rabbit serum. The mixture was frozen after adding glycerol.

\section{RESULTS AND CONCLUSIONS}

The results of three consecutive experiments are presented in the table. It will be observed that there was usually a slight increase in viable count after freezing and thawing, presumably due to disaggregation of clumps; the contents of tubes processed simultaneously had comparable viable counts; and the addition of a freezing protectant was unnecessary.

\section{TABLE}

VIABLE COUNTS (MILLIONS OF COLONY-FORMING UNITS) PER MILLIGRAM OF STABILATE BEFORE AND 48 HOURS AFTER FREEZING

\begin{tabular}{|c|c|c|c|}
\hline \multirow[t]{2}{*}{ Strain } & \multirow[t]{2}{*}{ Preservative } & \multicolumn{2}{|l|}{ Count $^{1}$} \\
\hline & & Before Freezing & After Freezing \\
\hline $\begin{array}{l}V . \text { cholerae } \\
12 \mathrm{R}\end{array}$ & $\begin{array}{l}\text { Nil } \\
\text { Glycerol } \\
\text { Dimethyl- } \\
\quad \text { sulphoxide }\end{array}$ & $\begin{array}{l}16 \cdot 9,18 \cdot 1 \\
21 \cdot 5 \\
16,16\end{array}$ & $\begin{array}{l}19,21 \cdot 2 \\
21,24\end{array}$ \\
\hline $\begin{array}{l}V \text { cholerae } \\
12 \mathrm{R}\end{array}$ & Glycerol & $18 \cdot 4,15 \cdot 5,18 \cdot 6$ & $18 \cdot 1,17,16 \cdot 5^{2}$ \\
\hline V. eltor & $\begin{array}{l}\text { Nil } \\
\text { Glycerol }\end{array}$ & $\begin{array}{l}5 \cdot 5,4 \cdot 4,4 \cdot 5 \\
4 \cdot 4,4 \cdot 5\end{array}$ & $\begin{array}{l}4 \cdot 2,5 \\
5 \cdot 2,5 \cdot 5,6 \cdot 1\end{array}$ \\
\hline
\end{tabular}

'Each count represents one tube, corrected for dilution by preservative. ${ }^{2}$ Counts after five months: $17 \cdot 1,14 \cdot 1$.

The count in the diarrhoea fluid was reduced from 1.3 million colony-forming units per milligram of the mixture with serum and glycerol to 0.4 million colonyforming units.

It thus seems practicable to store at low temperatures moderately dense suspensions of vibrio cultures without cell death. Perhaps even cholera stool can be preserved directly; it will be of interest to investigate various freezing protectants for this pupose.

We are indebted to Professor R. Cruickshank for his help and advice during the experiments and the preparation of the manuscript, and for providing the senior author with a research grant.

\section{REFERENCES}

Cunningham, M. P., Lumsden, W. H. R., and Webber, W. A. F. (1963). Exp. Parasit., 14, 280.

Fry, R. M., and Greaves, R. I. N. (1951). J. Hyg. (Lond.), 49, 220. Lumsden, W. H. R., and Hardy, G. J. C. (1965). Nature (Lond.), 205,1032 .

Maaloe, O. (1955). Bull. Wld Hlth Org., 12, 769.

McIntyre, O. R., and Feeley, J. C. (1964). J. infect. Dis., 114, 468.

Martin, S. M. (1964). Ann. Rev. Microbiol., 18, 1.

\section{Letter to the Editor}

PREPARATION OF BILIRUBIN STANDARDS

Dear Sir,

The instability of bilirubin in strong alkali led to search for an organic solvent, miscible with water, whiclo could be used to prepare a reliable bilirubin standard for routine use.

It was found that bilirubin is freely soluble in dimethyl sulphoxide which is water-miscible and in which serung proteins are easily dispersed. A solution of bilirubin iof this solvent shows an absorption peak at $453 \mathrm{~nm}$. with curve shape similar to that of a chloroform solution. $\vec{\theta}$

The stability in this solvent, whilst not approachin\& that in non-polar solvents, is better than that in aqueous alkali. No change in optical density was noted withike 15 minutes of dissolution, and the fall in optical densitg after 30 minutes in a $0.01 \mathrm{mM}$ solution approximated $0.25 \mu \mathrm{M} /$ hour. This indicated that although a simple solution in dimethylsulphoxide would not be adequately stable for use as a standard, the solvent could be used to prepare a stable standard in aqueous albumin.

The diluent used is $5 \%$ bovine albumin in wateo buffered to $p \mathrm{H} 7.4$ by phosphate buffer. A given weight of bilirubin of molar extinction $60,700 \pm 800$ is dissolve in $5 \mathrm{ml}$. of dimethylsulphoxide. When dissolution is coms plete this solution is made to $100 \mathrm{ml}$. with the diluent.

This standard is checked spectrophotometrically b\% adding $0.2 \mathrm{ml}$. to $3.8 \mathrm{ml}$. of dimethylsulphoxide, mixing and reading at $453 \mathrm{~nm}$. A blank is prepared by adding $0.2 \mathrm{ml}$. of diluent to $3.8 \mathrm{ml}$. dimethylsulphoxide. The optical density is multiplied by $19 \cdot 26$ (based on E 60,700 , to give the bilirubin concentration of the standard i $\mathrm{mg} . / 100 \mathrm{ml}$. The standard is then dispensed in smal. quantities for storage by deep freezing. The stability $\frac{0}{0}$ the standard prepared in this way appears to be bette? than 30 days at $-20^{\circ} \mathrm{C}$.

The ability of dimethylsulphoxide to disperse serum protein suggested the possibility of estimating bilirubiR directly at $453 \mathrm{~nm}$. As shown by Heilmeyer (1943), other coloured components in serum, principally haemoglobis and carotenoids, interfere considerably. It was noted thas the addition of one drop of 100 -volume hydrogen pete oxide to the test as described above gave a $60 \%$ reduction in the non-bilirubin colour whilst reducing the optican density of a $3.5 \mathrm{mg} \%$ bilirubin solution by only $7 \%$ Although obviously unsuitable for a true quantitatipe estimation, this technique may well prove of value in the rapid estimation of raised bilirubin levels in unhaemolyse sera.

Public Health Laboratory, K. G. GADD $\stackrel{\leftrightarrow}{\frac{C}{D}}$

Salisbury, Rhodesia. 